\title{
Job Safety Analysis during Tunnel Construction
}

\author{
Anjay Kumar Mishra*, \& P. S. Aithal** \\ *Post Doctoral Research Scholar, Srinivas University, India and Associate Professor, Madan \\ Bhandari Memorial Academy Nepal, Urlabari 3, Morang, Nepal \\ OrcidID: 0000-0003-2803-4918; Email: anjaymishra2000@gmail.com \\ ***Professor, College of Management \& Commerce, Srinivas University, Mangalore, India \\ OrcidID: 0000-0002-4691-8736; E-mail: psaithal@gmail.com
}

Subject Area: Business Management.

Type of the Paper: Project Management Action Research.

Type of Review: Peer Reviewed as per $|\mathrm{C}| \mathrm{O}|\mathrm{P}| \mathrm{E} \mid$ guidance.

Indexed In: OpenAIRE.

DOI: http://doi.org/10.5281/zenodo.4842501

Google Scholar Citation: IJAEML

\section{How to Cite this Paper:}

Mishra, Anjay Kumar, \& Aithal, P. S., (2021). Job Safety Analysis during Tunnel Construction. International Journal of Applied Engineering and Management Letters (IJAEML), 5(1), 80-96. DOI: http://doi.org/10.5281/zenodo.4842501.

International Journal of Applied Engineering and Management Letters (IJAEML)

A Refereed International Journal of Srinivas University, India.

Crossref DOI : https://doi.org/10.47992/IJAEML.2581.7000.0094

(c) With Authors.

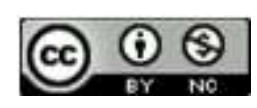

This work is licensed under a Creative Commons Attribution-Non-Commercial 4.0 International License subject to proper citation to the publication source of the work.

Disclaimer: The scholarly papers as reviewed and published by the Srinivas Publications (S.P.), India are the views and opinions of their respective authors and are not the views or opinions of the S.P. The S.P. disclaims of any harm or loss caused due to the published content to any party. 


\title{
Job Safety Analysis during Tunnel Construction
}

\author{
Anjay Kumar Mishra*, \& P. S. Aithal** \\ *Post Doctoral Research Scholar, Srinivas University, India and Associate Professor, Madan \\ Bhandari Memorial Academy Nepal, Urlabari 3, Morang, Nepal \\ OrcidID: 0000-0003-2803-4918; Email: anjaymishra2000@ gmail.com \\ **Professor, College of Management \& Commerce, Srinivas University, Mangalore, India \\ OrcidID: 0000-0002-4691-8736; E-mail: psaithal@gmail.com
}

\begin{abstract}
Purpose: There are many tunnels under construction in Nepal as its mountainous country. Road, water supply, hydropower, and irrigation projects are under construction in Nepal through the tunnel. "Safety First" should be one of the main objectives of any construction projects mainly tunnel and shall be given high priority throughout the construction period. A single person alone cannot do it alone. A team including safety professionals to concentrate on health, safety, and environmental concerns shall be involved to ensure that safety environment will be maintained in the construction site. OSH is the relation between man and man, man and machine and man and environment. The paper aims to analyze the job safety of major selected construction activities during tunneling.

Design/Methodology/Approach: Site Observation, Key Informant Interview (KII), and Study of Methods of Statement were done as main data collection tools. Job safety analysis and identification of activity with high risk level involved should be determined so that proper prevention and control mechanism could be determined and implemented. Drilling, excavation, blasting, mocking, scaling and shotcerting were major activities whose hazards, prevention mechanism and the responsible party were identified.

Findings/Result: The study reveals that the main occupational hazards were mechanical and chemical hazards. Rockfall and landslide were noted as the major mechanical hazard whereas toxic gas and cement dust were the main chemical hazards. Similarly, noise and vibration were the main physical hazards and untimely payment of wages and leave were psychological hazards. It was reported that the major accident occurred at sites where the leg struck on steps of boomer while pulling a worker to save him from falling of boomer, penetration by fine grinding wheel material into the eye while carrying out grind cutting of drum and faint due to oxygen deficiency inside the tunnel. Some minor accidents were road traffic accidents, cut by sharp tools, fall/hit to/hit by objects, splashing of acids, burning caught by fire, etc. and the fatal accidents was one of the mechanics blown away by the erupted boomer tyres while filling up air into the same and one of the workers lost his life due to truck accident inside the work premise. The families of the demised had been compensated by the company. For safe construction requires the teamwork of sincere and coordinated effort of all stakeholders. Lack of regular inspection and monitoring at the site was the main cause of improper implementation of prevailing health and safety regulations.
\end{abstract}

Originality/Value: The study is highly significant for working engineers to perform the task without any misfortune inside the tunnel.

Paper Type: Project Management Action Research.

Keywords: Activities, Hazards, Risk Control Measures, Responsible party

1. INTRODUCTION :

Safety determines site performance. Lingard \& Rowlinson (2005) [1] through their study concluded that execution at the site is always prone to these workers being exposed to various risks associated with construction works and other work-related diseases/ health hazards that physically and mentally affect the employees. The projects are delayed as a result of this because of the loss of working hours 
and legal hassles associated while mitigating the adversaries. Safety management can ensure the improvement of occupational safety at the construction site.

Nepal being a developing country, tunnel construction and safety practices in tunnel construction are a new topic. Accident related with the ignorance of safety leads to death of the worker. The cost associated with the safety can be huge be it direct cost or indirect cost. Tunneling is very dangerous engineering work as there are many hazards present as it is a risky underground construction so more preventive measures should be adopted. Currently, lots of tunneling works are going on in Nepal therefore it is necessary to understand safety related provisions and measures in Tunnel construction. it will also provide the framework for Job Safety Analysis of major activities of tunnel construction.

\section{OBJECTIVES :}

The focus of the research is to analyze the job safety of major activities during tunnel construction within Nepal.

\section{LITERATURE REVIEW :}

\subsection{Job Safety Analysis:}

Job Safety Analysis is one of the most effective tools to control accidents through proactive approaches which increases work productivity and project performance (Mishra \& Aithal, 2021) [2]. It is a widely accepted approach of the construction industry for safe site management throughout the project.

\subsection{Process of JSA:}

According to Mishra and Aithal (2021) [2], JSA confides in the following steps.

1. Specify the job and break it into tasks for knowing possible hazards.

2. Assign the relative level of Risks of those specified hazards.

3. Perform elimination, substitution, Engineering Control, Administrative control, and Provide proper and suitable personal protective equipment.

\subsection{Activities in Tunnel Construction: (based on a study by Lama et al, 2019 [3])}

a. Drill: During drilling assure rock quality, use of holes and its drilling through effective pickup track and jumbo forward and backward velocity, Geological application to sketch the tunnel face, and very importantly workmanship for drilling.

b. Blast: During blasting charging the holes, blast followed by ventilation where pick-up track both direction velocity, workmanship and timing are to be maintained.

c. Muck: Removal of loosened rock pieces, loading and hauling the debris out of the tunnel which needs effective excavation velocity, workmanship, loader velocity, and truck velocity.

d. Primary Support: Proper use of shotcrete using wire mesh, arch profile and rock bolts based on topographic assessment with careful shotcrete pump velocity management, Mixer both directional velocity, workmanship for spraying concrete, pick-up track movement, wire mesh installation skill, survey engineering skill for setting steel arc profile, loader movement, and workmanship for drilling rock bolts, installing steel arch profile and all.

\section{RESEARCH METHODOLOGY :}

\subsection{Study Area: Melamchi Tunnel:}

The total length of the water tunnel was $27,584 \mathrm{~m}$ of which excavated length of the water tunnel at Ambathan downstream was about $3549.4 \mathrm{~m}$ out of $4321 \mathrm{~m}$, at Gyalthum Downstream was about $3730.8 \mathrm{~m}$ out of $3751 \mathrm{~m}$ and at Sindhu Upstream $3280.5 \mathrm{~m}$ out of $3698 \mathrm{~m}$. Excavation at Ambathan Upstream, Gyalthum Upstream, Sindhu downstream and sundarijal were completed. In addition to water tunnel, there were 3 already excavated adit tunnels namely Ambathan adit tunnel with total length $298 \mathrm{~m}$, Gyalthum adit tunnel with total length $331 \mathrm{~m}$ and Sindhu Adit Tunnel with $752 \mathrm{~m}$. To sum up this, the total excavated length of the water tunnel till 9th of January, 2018 was about 27,078.9m. The cross-sectional area of the tunnel was $12.7 \mathrm{sqm}$ with D-shaped cross section. The tunnel was being constructed by drill and blast method. The design discharge of the tunnel was 6 cumec to bring 51 Crore lpd. The tunnel was supported by shotcreting and rock bolting permanently [4] \& [5]. 


\subsection{Data Collection:}

\subsubsection{Primary data}

Primary data were the main data for the analysis and interpretation of result for this research work. Primary data was collected in three ways:

\section{Site visit:}

Site observation was done of four adits which had been used as one of the data collection method. So, it was used to identify occupational hazards, risks and accident as well as it was used to analyze the job safety practices.

Focus Group Discussion:

Focus group discussions (FGD) were done to find out the effective implementation of safety measures and regulations as per contract document. The subject of focus group discussion was limited to:

- Identify various occupational hazards, risks and accident presents in the tunnel.

- Investigate various safety measures adopted and practiced by workers.

Key Informant Interview:

KII regarding safety was performed on various key personnel from Employer, Engineer and Contractor for different safety practices adopted and could have been adopted at Tunnel construction.

\subsubsection{Literature Review}

These include safety related books, notes, journals, articles, published data from Government agencies, papers, thesis reports, websites, and safety related documents of the Melamchi project.

\subsection{Data Analysis:}

After the collection of primary and secondary data, all these data were used for job safety analysis tables.

\subsection{Research Matrix:}

As summarized in the table below for the research matrix, the information was collected from the different stakeholders to evaluate their knowledge and information regarding the implementation of safety practices and regulations in Melamchi Tunnel. KII and focus group discussion along with direct observation was the main tools used for the data collection.

Table1: Research matrix

\begin{tabular}{|l|l|l|l|l|}
\hline Objective & $\begin{array}{l}\text { Information } \\
\text { required }\end{array}$ & Data source & Methodology & Output \\
\hline $\begin{array}{l}\text { To analyze the job } \\
\text { safety of major } \\
\text { activities of tunnel } \\
\text { construction. }\end{array}$ & $\begin{array}{l}\text { Various stages of } \\
\text { specific jobs, } \\
\text { Relative level of } \\
\text { risk, } \\
\text { Different measures } \\
\text { taken to reduce or } \\
\text { eliminate the risk. }\end{array}$ & $\begin{array}{l}\text { Work } \\
\text { Breakdown } \\
\text { Structure, } \\
\text { Risk } \\
\text { Assessment } \\
\text { Chart, } \\
\text { Checklist, } \\
\text { Standard } \\
\text { Formats. }\end{array}$ & $\begin{array}{l}\text { Site Observation, } \\
\text { KII } \\
\text { Study of Methods } \\
\text { of Statement }\end{array}$ & $\begin{array}{l}\text { Job Safety } \\
\text { Analysis of major } \\
\text { activities of } \\
\text { Melamchi Tunnel. }\end{array}$ \\
\hline
\end{tabular}

\section{RESULTS AND DISCUSSION :}

\section{Job Safety Analysis of Major Activities:}

The main health problems faced due to hazards were wrist pain, back pain as well as being faint and deaf. The riskiest activities during tunnel construction were drilling and blasting. The Key Informant stated that $50 \%$ workers, $17 \%$ client, $17 \%$ Contractor, $25 \%$ consultant and $8 \%$ government were responsible for accident at site. About $48 \%$ employers and $40 \%$ workers responded that preventive measures are effective 0in tunnel during construction phase. It clearly indicates that proper safety plan and implementation is still remaining to do to enhance productivity and to ensure the workers that they are safe.

Use of PPEs, administrative control and Engineering Control were the control measures adopted for tunnel construction. Elimination and substitution were generally not adopted though these are the best control measures for hazard control. It was observed that the medical clinic was established and clinical services at each site were functioning well. The clinics were well equipped with sufficient medicines. 
Two medical staffs were appointed in each clinic to carry out assign duties each during day and night shift, respectively.

The issues of OSH in Nepal are still in infant stage. Despite of several efforts, so many things still remained to establish sound OSH environment. The assurance of effectively OSH in implementation as investment not expenditure with a hope of safe, productive and healthy work culture is not easy task. It depends on teamwork of sincere and coordinated effort of all stakeholders. Lack of regular inspection and monitoring at site was the main cause of improper implementation of prevailing health and safety regulations (Mishra and Joshi, 2021 [6]; Mishra and Sharestha, 2017 [7]). JSA of major activities in tunnel construction like excavation, loading and blasting, drilling, mucking, scaling and primary supports as shotcreting/ sprayed concreting can be presented as follow:

Table 2: Job Safety Analysis of Tunnel Excavation

\begin{tabular}{|l|l|l|l|}
\hline Company Name & Melamchi Diversion Scheme \\
\hline Site Name & GYALTHUM & \multicolumn{2}{l|}{} \\
\hline Contractor & CMC DI RAVENNA & \multicolumn{2}{l|}{} \\
\hline Activity & TUNNEL EXCAVATION \\
\hline $\begin{array}{l}\text { Activities List in } \\
\text { Sequence of } \\
\text { Performance }\end{array}$ & $\begin{array}{l}\text { Hazards } \\
\text { Identification }\end{array}$ & $\begin{array}{l}\text { Proactive Approaches } \\
\text { for controlling Risk } \\
\text { Measure }\end{array}$ & $\begin{array}{l}\text { Responsible } \\
\text { Professional }\end{array}$ \\
\hline $\begin{array}{l}\text { Survey and } \\
\text { Geological mapping }\end{array}$ & $\begin{array}{l}\text { i) Dust and Solvent. } \\
\text { ii) Ladder, Fall, Slip }\end{array}$ & $\begin{array}{l}\text { i) Mask and filter mask. } \\
\text { ii) Support, Good } \\
\text { housekeeping }\end{array}$ & $\begin{array}{l}\text { i) Survey In charge } \\
\text { ii) Tunnel supervisor }\end{array}$ \\
\hline Drilling and Charging & $\begin{array}{l}\text { i) Boomer, Noise, } \\
\text { Rock fall } \\
\text { ii) Explosives, } \\
\text { Detonators }\end{array}$ & $\begin{array}{l}\text { i) PPE and Support } \\
\text { system. } \\
\text { ii) Safe method of work }\end{array}$ & $\begin{array}{l}\text { i) Site In-charge } \\
\text { ii) Supervisor }\end{array}$ \\
\hline $\begin{array}{l}\text { Blasting and Mucking } \\
\text { work }\end{array}$ & $\begin{array}{l}\text { i) Post Blasting fume } \\
\text { and gaseous } \\
\text { ii) Rock-mass, low } \\
\text { visibility }\end{array}$ & $\begin{array}{l}\text { i) Defuming, PPE } \\
\text { ii) Support work, } \\
\text { Inspection }\end{array}$ & $\begin{array}{l}\text { i) Site In charge } \\
\text { ii) Blaster }\end{array}$ \\
\hline Support Work & $\begin{array}{l}\text { i) Shotcreting/ } \\
\text { Wiremess } \\
\text { ii) Rock Bolt/ Lattice } \\
\text { Girder }\end{array}$ & $\begin{array}{l}\text { i) Safe Method of work } \\
\text { ii) PPE }\end{array}$ & i) Site In-charge \\
\hline
\end{tabular}

Table 3: Job Safety Analysis of Loading and Blasting

\begin{tabular}{|l|l|l|l|}
\hline Company Name & Melamchi Diversion Scheme \\
\hline Site Name & AMBATHAN & \multicolumn{3}{l|}{} \\
\hline Contractor & CMC DI RAVENNA & \multicolumn{2}{l|}{} \\
\hline Activity & LOADING AND BLASTING \\
\hline $\begin{array}{l}\text { Activities List in } \\
\text { Sequence } \\
\text { Performance }\end{array}$ & $\begin{array}{l}\text { Hazards } \\
\text { Identification }\end{array}$ & $\begin{array}{l}\text { Proactive Approaches } \\
\text { for controlling Risk } \\
\text { Measure }\end{array}$ & $\begin{array}{l}\text { Responsible } \\
\text { Professional }\end{array}$ \\
\hline $\begin{array}{l}\text { Blasting material is } \\
\text { taken out from Army } \\
\text { Barrack. }\end{array}$ & $\begin{array}{l}\text { May blast during } \\
\text { transporting }\end{array}$ & $\begin{array}{l}\text { Detonator and } \\
\text { Explosive should be } \\
\text { carried differently. }\end{array}$ & Blaster and Army \\
\hline $\begin{array}{l}\text { Blasting material is } \\
\text { send inside the tunnel. }\end{array}$ & $\begin{array}{l}\text { May blast during } \\
\text { transporting inside the } \\
\text { tunnel }\end{array}$ & $\begin{array}{l}\text { Two vehicles should be } \\
\text { used to carry those } \\
\text { explosive material }\end{array}$ & Blaster \\
\hline $\begin{array}{l}\text { Blasting material is } \\
\text { loaded to the drilled } \\
\text { holes. }\end{array}$ & Misfire & $\begin{array}{l}\text { Properly (Carefully) } \\
\text { charged }\end{array}$ & Blaster \\
\hline
\end{tabular}




\begin{tabular}{|l|l|l|l|}
\hline $\begin{array}{l}\text { All the holes are } \\
\text { connected by wires. }\end{array}$ & $\begin{array}{l}\text { Only Blasters having } \\
\text { registered license of } \\
\text { blasting should be hired } \\
\text { and allowed to do this } \\
\text { work. }\end{array}$ & Blaster \\
\hline $\begin{array}{l}\text { Then move away } \\
\text { around 200m-300m } \\
\text { down. }\end{array}$ & $\begin{array}{l}\text { i) Misfire Can be Injured by } \\
\text { ii) } \\
\text { Blast material (rocks) }\end{array}$ & Do not Panic & Blaster \\
\hline Then Blasting & $\begin{array}{l}\text { Misfired due to wrong } \\
\text { wiring }\end{array}$ & $\begin{array}{l}\text { Keep distance and reach } \\
\text { to safe place }\end{array}$ & Blaster \\
\hline
\end{tabular}

Table 4: Job Safety Analysis of Drilling

\begin{tabular}{|c|c|c|c|}
\hline Company Name & \multicolumn{3}{|c|}{ Melamchi Diversion Scheme } \\
\hline Site Name & \multicolumn{3}{|c|}{ AMBATHAN } \\
\hline Contractor & \multicolumn{3}{|c|}{ CMC DI RAVENNA } \\
\hline Activity & \multicolumn{3}{|c|}{ DRILLING } \\
\hline $\begin{array}{l}\text { Activities List in } \\
\text { sequence }\end{array}$ & $\begin{array}{l}\text { Hazards } \\
\text { identification }\end{array}$ & Preventive Measures & $\begin{array}{l}\text { Responsible } \\
\text { Professional } \\
\end{array}$ \\
\hline $\begin{array}{l}\text { Boomer (equipment) } \\
\text { operation }\end{array}$ & Mechanical & Should be operated only by expert & Boomer operator \\
\hline $\begin{array}{l}\text { Boomer moved to the } \\
\text { drilling face }\end{array}$ & No & - & Boomer operator \\
\hline $\begin{array}{l}\text { Boomer connected } \\
\text { with electricity }\end{array}$ & Electricity & $\begin{array}{l}\text { Strong enforcement of Code of } \\
\text { Practice: } \\
\text { i) preparing for electrical risks } \\
\text { ii) standard operating procedure of } \\
\text { equipment before application }\end{array}$ & $\begin{array}{l}\text { Boomer operator } \\
\text { team }\end{array}$ \\
\hline $\begin{array}{l}\text { Boomer connect with } \\
\text { water and drill rod }\end{array}$ & $\begin{array}{l}\text { Loose rock } \\
\text { falling }\end{array}$ & $\begin{array}{l}\text { Careful walk down through tunnel } \\
\text { frequently and scaling where needed } \\
\text {-mechanically scaling and bolting } \\
\text {-installing ground support: } \\
\text { immediately applying overhead } \\
\text { protection in case of manual-changing } \\
\text { ground support methods }\end{array}$ & Foreman/Supervisor \\
\hline $\begin{array}{lll}\text { Drilling } & \text { started by } \\
\text { boomer } & & \end{array}$ & No & Use ear plugs & Operator \\
\hline $\begin{array}{l}\text { Around } 80-100 \text { holes } \\
\text { is been drilled of } \\
\text { around } 2 \mathrm{~m} \text { to } 2.8 \mathrm{~m} \\
\text { long }\end{array}$ & No & - & Operator \\
\hline $\begin{array}{l}\text { Rod / Pipe is installed } \\
\text { inside the drill hole to } \\
\text { clean the hole before } \\
\text { charging }\end{array}$ & No & Lift the rod/pipe carefully & $\begin{array}{l}\text { Operator } \\
\text { /Contractor }\end{array}$ \\
\hline $\begin{array}{l}\text { Detonator/Explosive } \\
\text { material is been } \\
\text { installed in holes }\end{array}$ & Misfire & $\begin{array}{l}\text { Explosive material should be handled } \\
\text { carefully }\end{array}$ & $\begin{array}{l}\text { Detonator installer/ } \\
\text { contractor }\end{array}$ \\
\hline $\begin{array}{l}\text { Connect all the wires } \\
\text { of detonator }\end{array}$ & Misfire & $\begin{array}{l}\text { Only Blasters having registered } \\
\text { license of blasting should be hired and } \\
\text { allowed to do this work. }\end{array}$ & Blaster \\
\hline Fire & $\begin{array}{l}\text { Rock falls or } \\
\text { tunnel collapse }\end{array}$ & $\begin{array}{l}\text { Do not Panic and move to safest } \\
\text { distance }\end{array}$ & Blaster \\
\hline
\end{tabular}


Table 5: Job Safety Analysis of Mucking

\begin{tabular}{|c|c|c|c|c|}
\hline Company Name & \multicolumn{4}{|c|}{ Melamchi Diversion Scheme } \\
\hline Site Name & \multicolumn{4}{|c|}{ AMBATHAN } \\
\hline Contractor & \multicolumn{4}{|c|}{ CMC DI RAVENNA } \\
\hline Activity & \multicolumn{4}{|c|}{ MUCKING - (After an hour of blasting) } \\
\hline \multicolumn{2}{|c|}{ Activities List in sequence } & Hazards identification & Preventive Measures & $\begin{array}{l}\text { Responsible } \\
\text { professional }\end{array}$ \\
\hline \multicolumn{2}{|c|}{$\begin{array}{l}\text { After } 1 \text { to } 1 \frac{1}{2} \text { hours for } \\
\text { defuming }\end{array}$} & $\begin{array}{l}\text { Harmful chemical } \\
\text { produced }\end{array}$ & $\begin{array}{l}\text { Good quality mask to be } \\
\text { used, good lighting to } \\
\text { work area }\end{array}$ & Driver \\
\hline \multicolumn{2}{|c|}{$\begin{array}{l}\text { Then haul loader / tipper is } \\
\text { transported to the mucking } \\
\text { site }\end{array}$} & Rock fall & $\begin{array}{l}\text { Driver have to be careful } \\
\text { while entering to the site }\end{array}$ & Driver \\
\hline \multicolumn{2}{|c|}{ Mucking started } & $\begin{array}{l}\text { Truck is loaded so break } \\
\text { fail or mechanical break } \\
\text { down and also chances of } \\
\text { collision, dust and noise }\end{array}$ & $\begin{array}{l}\text { Truck should be fully } \\
\text { serviced and maintain }\end{array}$ & Driver \\
\hline \multicolumn{2}{|c|}{$\begin{array}{l}\text { Muck is loaded and } \\
\text { transported away from the } \\
\text { face or worksite }\end{array}$} & Being struck or crushed & $\begin{array}{l}\text { Vehicle should be well } \\
\text { serviced, other people do } \\
\text { not enter into loading } \\
\text { area }\end{array}$ & Driver \\
\hline \multicolumn{2}{|c|}{$\begin{array}{l}\text { Muck removal using } \\
\text { conveyance system or a } \\
\text { muck bucket, muck box, } \\
\text { muck cart, or muck car. }\end{array}$} & $\begin{array}{l}\text { Chemical hazard, Falling } \\
\text { material }\end{array}$ & $\begin{array}{l}\text { Musk equipment should } \\
\text { be handled with care and } \\
\text { should be used properly }\end{array}$ & Labor / driver \\
\hline \multicolumn{2}{|c|}{$\begin{array}{l}\text { muck transported to the } \\
\text { surface using the } \\
\text { conveyor via horizontal, } \\
\text { inclined, vertical or } \\
\text { combination of horizontal } \\
\text { and vertical route to its } \\
\text { final destination }\end{array}$} & Tripping and falling & $\begin{array}{l}\text { Keep running surface in } \\
\text { good condition }\end{array}$ & Driver \\
\hline \multicolumn{2}{|c|}{$\begin{array}{l}\text { The final destination is a } \\
\text { stock pile where the muck } \\
\text { is dumped and also can be } \\
\text { re used from the disposal } \\
\text { place. }\end{array}$} & $\begin{array}{l}\text { Overturn and fall of } \\
\text { vehicle while dumping, } \\
\text { tripping and falling }\end{array}$ & $\begin{array}{l}\text { Should take care while } \\
\text { dumping and one person } \\
\text { should be there on back } \\
\text { side of vehicle }\end{array}$ & Driver \\
\hline
\end{tabular}

Table 6: Job Safety Analysis of Scaling

\begin{tabular}{|c|c|c|c|}
\hline Company Name & \multicolumn{3}{|c|}{ Melamchi Diversion Scheme } \\
\hline Site Name & \multicolumn{3}{|c|}{ AMBATHAN } \\
\hline Contractor & \multicolumn{3}{|c|}{ CMC DI RAVENNA } \\
\hline Activity & \multicolumn{3}{|c|}{ SCALING } \\
\hline $\begin{array}{l}\begin{array}{l}\text { Activities List in } \\
\text { sequence }\end{array} \\
\end{array}$ & $\begin{array}{l}\text { Hazards } \\
\text { identification }\end{array}$ & $\begin{array}{l}\text { Preventive Control } \\
\text { Measures }\end{array}$ & $\begin{array}{l}\text { Professional } \\
\text { Responsibility } \\
\end{array}$ \\
\hline \multirow{3}{*}{$\begin{array}{l}\text { The detached rock in } \\
\text { the crown should be } \\
\text { removed from crown } \\
\text { by using scaling stick } \\
\text { on the other vehicle }\end{array}$} & $\begin{array}{l}\text { Rock can fall on the } \\
\text { human or worker. }\end{array}$ & $\begin{array}{l}\text { Proper scaling should be } \\
\text { carried out }\end{array}$ & Foreman/supervisor \\
\hline & Rock fall & $\begin{array}{l}\text { Use machine for rock } \\
\text { scaling }\end{array}$ & \\
\hline & $\begin{array}{l}\text { Collapse as result from } \\
\text { instability of exposed }\end{array}$ & $\begin{array}{l}\text { enter only after scaling is } \\
\text { done in risky zone }\end{array}$ & \\
\hline
\end{tabular}




\begin{tabular}{|l|l|l|l|}
\hline & rock surface & & \\
\hline & & Sufficient Lighting & \\
\hline Manual Scaling & Falling from heights & Use working platforms & \\
\hline & Being crushed & $\begin{array}{l}\text { Only work from a safe } \\
\text { area }\end{array}$ & \\
\hline & & Area should be lightened. & \\
\hline
\end{tabular}

Table 7: Job Safety Analysis of Shotcreting or Sprayed Concrete

\begin{tabular}{|c|c|c|c|}
\hline Company Name & \multicolumn{3}{|c|}{ Melamchi Diversion Scheme } \\
\hline Site Name & \multicolumn{3}{|c|}{ AMBATHAN } \\
\hline Contractor & \multicolumn{3}{|c|}{ CMC DI RAVENNA } \\
\hline Activity & \multicolumn{3}{|c|}{ SHOTCRETING OR SPRAYED CONCRETE } \\
\hline $\begin{array}{l}\text { Activities List in } \\
\text { sequence }\end{array}$ & $\begin{array}{l}\text { Hazards } \\
\text { identification }\end{array}$ & $\begin{array}{l}\text { Preventive Control } \\
\text { Measures. }\end{array}$ & $\begin{array}{l}\text { Responsible } \\
\text { professional }\end{array}$ \\
\hline $\begin{array}{l}\text { Shotcrete is a } \\
\text { commonly used term } \\
\text { for sprayed concrete. } \\
\text { Shotcrete is mortar or } \\
\text { concrete conveyed } \\
\text { through a hose and } \\
\text { pneumatically } \\
\text { projected at high } \\
\text { velocity onto a } \\
\text { surface. }\end{array}$ & $\begin{array}{l}\text { Cement dust, ammonia } \\
\text { and chemical } \\
\text { accelerating } \\
\text { compounds. }\end{array}$ & & \\
\hline $\begin{array}{l}\text { Transporting concrete } \\
\text { in large plant, usually } \\
\text { in confined spaces with } \\
\text { poor lighting }\end{array}$ & $\begin{array}{l}\text { cement or chemical } \\
\text { additives }\end{array}$ & $\begin{array}{l}\text { i) providing: } \\
\text { a. exclusion zones } \\
\text { and traffic } \\
\text { management planning } \\
\text { b. lighting on the plant } \\
\text { and at the work face } \\
\text { c. plant reversing } \\
\text { alarms } \\
\text { ii) using suitable PPE } \\
\text { including high- } \\
\text { visibility protective } \\
\text { clothing }\end{array}$ & Operator \\
\hline $\begin{array}{l}\text { Transferring the } \\
\text { concrete to the } \\
\text { conveyor }\end{array}$ & Cement dust, rebound & $\begin{array}{l}\text { i) providing guarding } \\
\text { to prevent entry to the } \\
\text { conveyor unit } \\
\text { ii) using suitable PPE } \\
\text { including splash } \\
\text { protection for eyes }\end{array}$ & Operator \\
\hline $\begin{array}{l}\text { Conveying the } \\
\text { concrete }\end{array}$ & Plant electrical supply & $\begin{array}{l}\text { i) providing: } \\
\text { a. regular servicing of } \\
\text { the plant according to } \\
\text { the maintenance plan } \\
\text { including checking } \\
\text { conveyor tubes and } \\
\text { hoses } \\
\text { b. relevant training to } \\
\text { plant operators and } \\
\text { mechanics }\end{array}$ & Operator \\
\hline Applying concrete & Direct Eye or skin & i) providing exclusion & Operator \\
\hline
\end{tabular}




\begin{tabular}{|l|l|l|l|}
\hline $\begin{array}{l}\text { contact which causes } \\
\text { chemical burns, } \\
\text { poisoning and other } \\
\text { toxic effects, Burst of } \\
\text { concrete hose }\end{array}$ & $\begin{array}{l}\text { zones and restricting } \\
\text { involved in the } \\
\text { concrete application } \\
\text { ii) using suitable PPE } \\
\text { including impact- } \\
\text { resistant goggles, } \\
\text { helmet, gloves, } \\
\text { breathing apparatus, } \\
\text { hearing protection, } \\
\text { safety boots and full } \\
\text { body clothing }\end{array}$ \\
\hline $\begin{array}{l}\text { After applying } \\
\text { concrete }\end{array}$ & Slips, trips and falls & $\begin{array}{l}\text { i) ensuring no entry to } \\
\text { enprotected, security } \\
\text { established freshly } \\
\text { sprayed areas }\end{array}$ & \\
\hline
\end{tabular}

A proper linear responsibility chart (LRC) and checklist, work permit facility should be strongly enforced. The LRC assures a complete responsibility of professional involved and checklist assures task to be performed and approval process will reconfirm emergency plans to facilities and overall check. The effectiveness of safety measures has been assessed by Mishra et al, 2019 [8] in tunnel construction with proper advice for improvement which might increase the performance of industry resulting in productivity of the industry as Chiluwal and Mishra, 2017 [9] have highlighted the need of hydropower project improvement. Every project should be properly implemented based on OSHA [10] rules and effective tunneling engineering [11] application would be highly effective before construction.

\section{CONCLUSION :}

The assurance of Occupational Safety and Health in Nepal needs overall revision. Despite of several efforts, so many things still remained to establish a sound OSH environment. The task of enforcing OSH investment as an investment for a safe and healthy work environment is necessary. It should have teamwork of sincere and coordinated effort of all stakeholders. Lack of regular inspection and monitoring at the site was the main cause of improper implementation of prevailing health and safety regulations. Job safety analysis and identification of activity with high risk level involved should be determined so that proper prevention and control mechanism could be determined and implemented. Drilling, excavation, blasting, mocking, scaling and shotcerting were major activities whose hazards, prevention mechanism and responsible party were identified. Management should review job safety plans in the interval of a fixed time for improvement and conduct safety training to workers frequently to reduce the rate of near-miss and mishap accidents at the construction sites.

\section{RECOMMENDATIONS :}

\section{Government:}

Following recommendations could be made to Government:

- Effective implementation of existing Labor Laws on OSH

- Separate policies should be formulated based on the type of construction and geographical area of the construction site. The risk and the protective measures to be implemented vary from one sector to another.

\section{Employers:}

The role of the Employer is to monitor the OSH conditions of the site and provide required back up to Engineers. Following recommendations could be made to Employers:

- Cooperate to coordinate with concerned stakeholders and agencies to conduct OSH training.

- Regularly monitor whether PPEs have been used properly by workers or not and whether the mitigation measures have been implemented or not at construction site.

- Provide necessary comments and suggestions for further improvement, if required, regarding the $\mathrm{OSH}$ issues of the construction site. 


\section{Engineers:}

Engineers should play a vital role to maintain the proper safe and healthy working environment of construction site to prevent from occupational hazards. Following recommendations could be made to Engineers:

- Regular monitor whether PPEs have been effectively used by workers or not and make mandatory to use PPEs. If PPEs have not been suitably and properly used, the Contractor shall be instructed to provide required PPEs to workers.

- Regular monitor whether the protective measures have been implemented or not. If not, the Engineer should instruct the Contractor for proper implementation of protective measures.

- Regular monitoring of the record keeping system of accidents maintained by Contractor, whether regular checkup of workers done or not.

- Regular monitor whether pure drinking water has been provided to workers or not and whether proper sanitation and drainage system has been maintained or not.

- Regularly monitor whether regular maintenance of equipment has been done or not.

- Instruct the Contractor if any improvements to be made and regularly follow up whether the instruction has been followed or not.

- Facilitate the Contractor to conduct the regular OSH training and meeting with workers.

\section{Contractor:}

It is often blamed that the Contractor is not serious enough regarding OSH issues means they usually ignore the OSH issues. Hence it is the duty of Contractor to maintain the construction site safe and healthy and the following recommendations could be made to Contractors:

- Installation of warning sign boards and isolation of the construction site by barricading it and prevent entry of unauthorized personnel at site.

- Encourage the workers to maintain the healthy and safe working environment by providing rewards.

- Contractor should appoint safety personnel with relevant and necessary expertise.

- Manage proper electric wiring in order to ensure that not any unwanted accidents will occur at construction site due to electric shock or leakage.

- Maintain proper first aid treatment facilities, manage regular health checkup of workers and staffs at construction site.

- Maintain medical and accident insurance of all workers.

- Make necessary arrangements for medical treatment at nearby hospitals.

- Maintain the systematic record keeping system of any accidents whether minor injury or major injury including death of person and report it to Engineers and Employers.

- Manage necessary arrangement to ensure safety against fire.

- Maintain a reasonable mechanism of compensation to workers.

- Provide pure drinking water to workers and maintain proper sanitation and drainage system to ensure hygienic environment at the construction site.

- Provide non-hazardous work to pregnant women workers and maternity leave and facilities as mentioned in Labor Act.

- Provide a separate smoking zone.

Workers:

- Share the knowledge among co-workers.

- Inform the management if any improvement to be made regarding health and safety condition of the site.

- Workers should be made aware of their rights mentioned in the Labor Act.

- Avoid child labor at the construction sites.

The requirements of Occupational Safety and Health issues shall be clearly indicated in the Contract Documents and should be agreed and compulsorily implemented at the time of execution of the project. The budget should be allocated for OSH issues so that they could be effectively implemented during construction.

\section{REFERENCES :}

[1] Lingard, H. \& Rowlinson, S. M., (2005). Occupational Health and Safety in Construction Project 
Management. Routledge, Spon Press, ISBN 0-419-26210-5.

[2] Mishra, A. K., \& Aithal, P. S., (2021). Operational Risk Analysis of Common Activities of Building Construction Project. Turkish Journal of Computer and Mathematics Education, 12(11), 65076524.

[3] Lama, C., Sah, D. P., \& Mishra, A. K. (2019). Occupational Hazards Identification and Their Risk Assessment during the Construction of Head Race Tunnel in Middle Bhotekoshi Hydroelectric Project. International Journal of Research-Granthaalayah, 7(3), 227-248.

[4] Nippon Koei (2000). Kathmandu valley water supply development program (including Melamchi) - Program document. Final report, Vol. 1 and 2, https://www.melamchiwater.gov.np.

[5] Norplan A. S. (2003). Melamchi diversion scheme: update of hydrology report - 2002. Report to the Melamchi Water Supply Development Board, 32, https://www.melamchiwater.gov.np

[6] Mishra, A. K., \& Joshi, K. R. (2020). Practice of Safety Culture Principles. PalArch's Journal of Archaeology of Egypt/Egyptology, 17(6), 13986-13998.

[7] Mishra, A. K., \& Shrestha, M. (2017). Health and Safety Status of Casual Workers in Road Improvement Project Kathmandu Valley, Nepal. International Journal of Engineering Technology Science and Research (IJETSR), 4(9), 1187-1199.

[8] Mishra A. K. Lama C., Sah D. P., et al. (2019). Effectiveness Assessment of Preventive and Control Measures of Safety Implementation. J. Adv Res Civil Envi Engr, 6(2), 1-20.

[9] Chiluwal K. and Mishra A. K., (2018). Impact of performance on profitability of small hydropower projects in Nepal. International Journal of Current Research, 10(01), 63918-63925.

[10] Hu, L.H., Huo, R., Peng, W., Chow, W. K. and Yang, R. X., (2006). On the maximum smoke temperature under the ceiling in tunnel fires. Tunnelling and Underground Space Technology, $21(6), 650-655$.

[11] OSHA, 2002. Osha Publications. [Online] Available at: https://www.osha.gov/Publications/osha3071.pdf 


\section{Appendix}

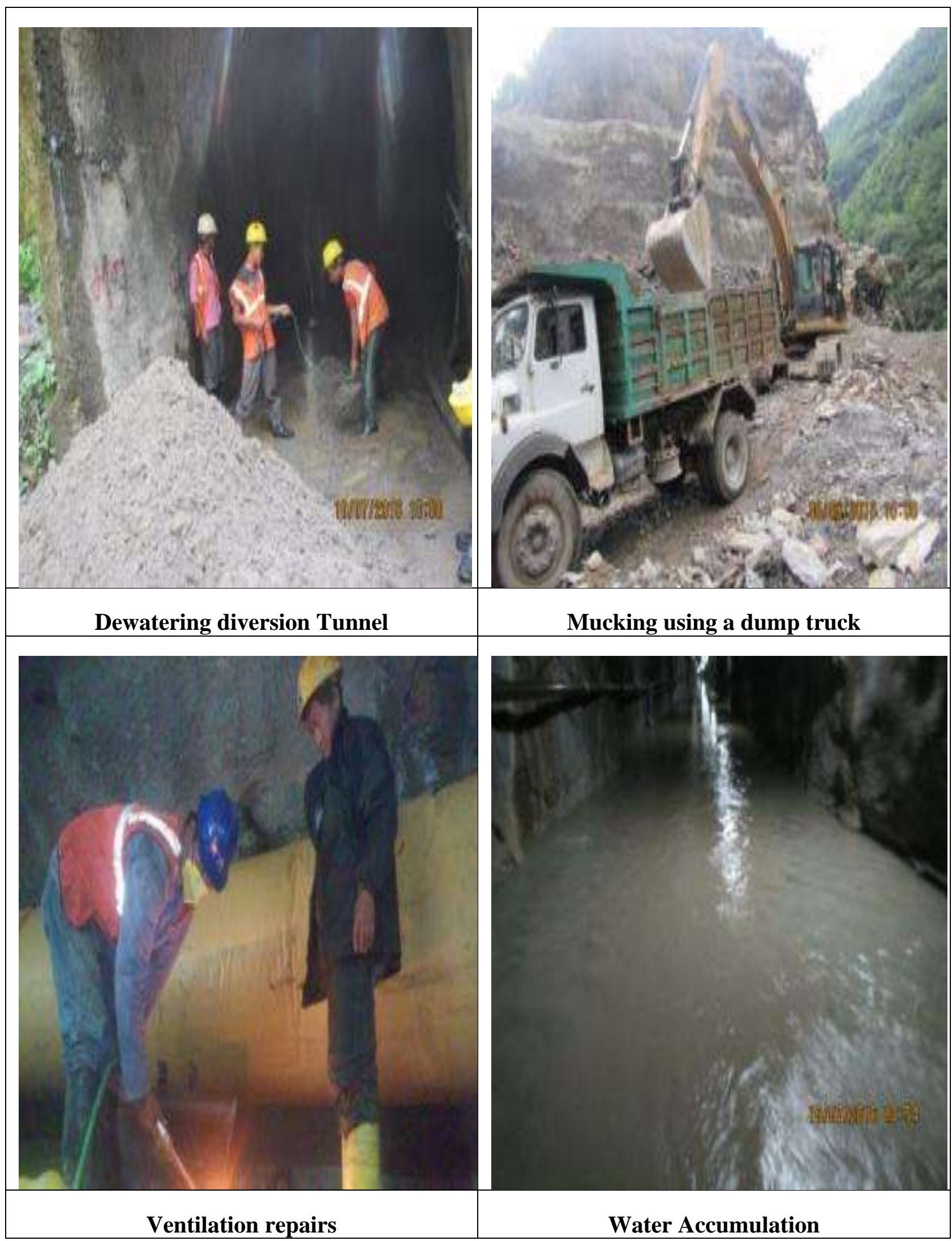




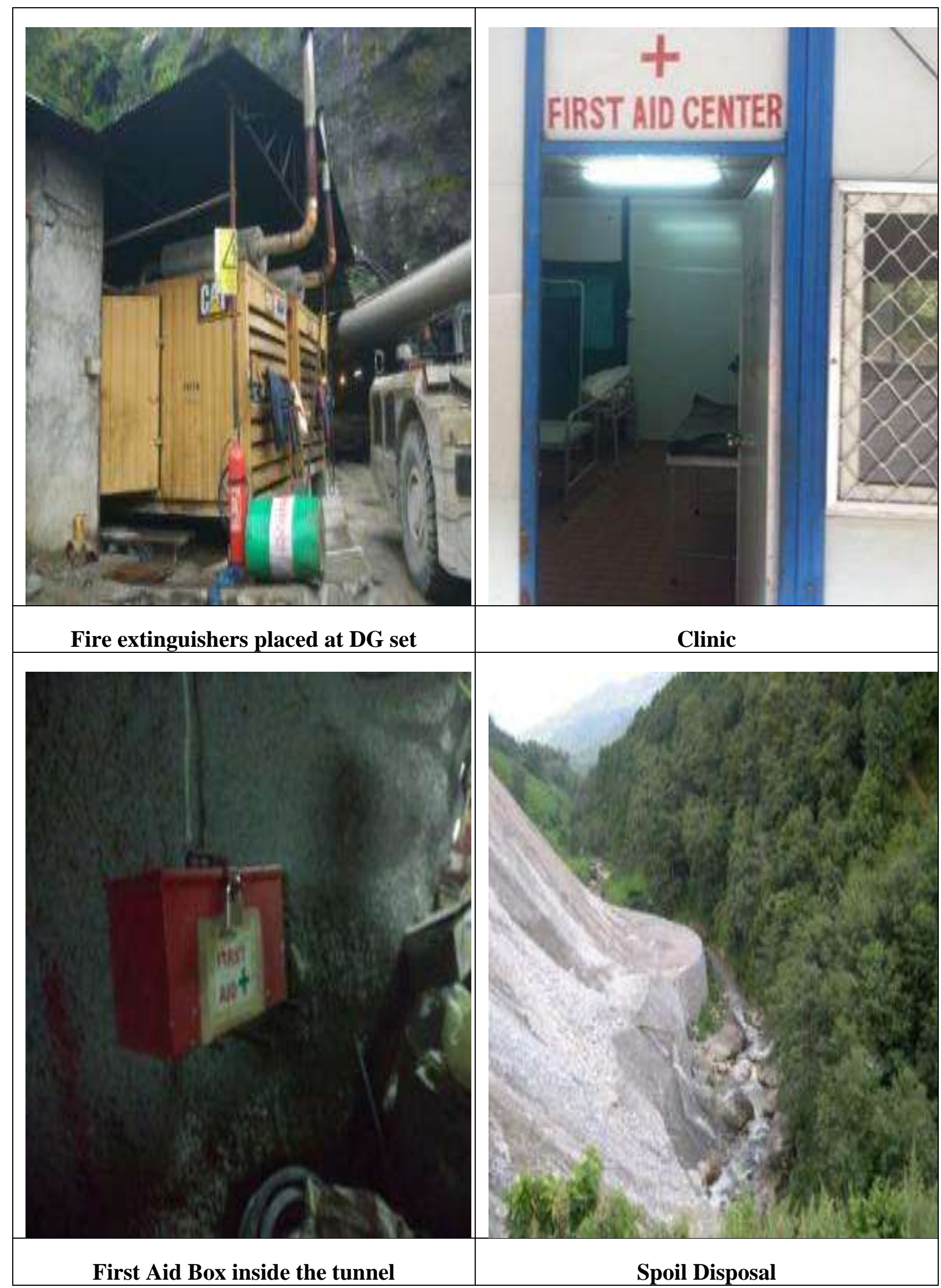




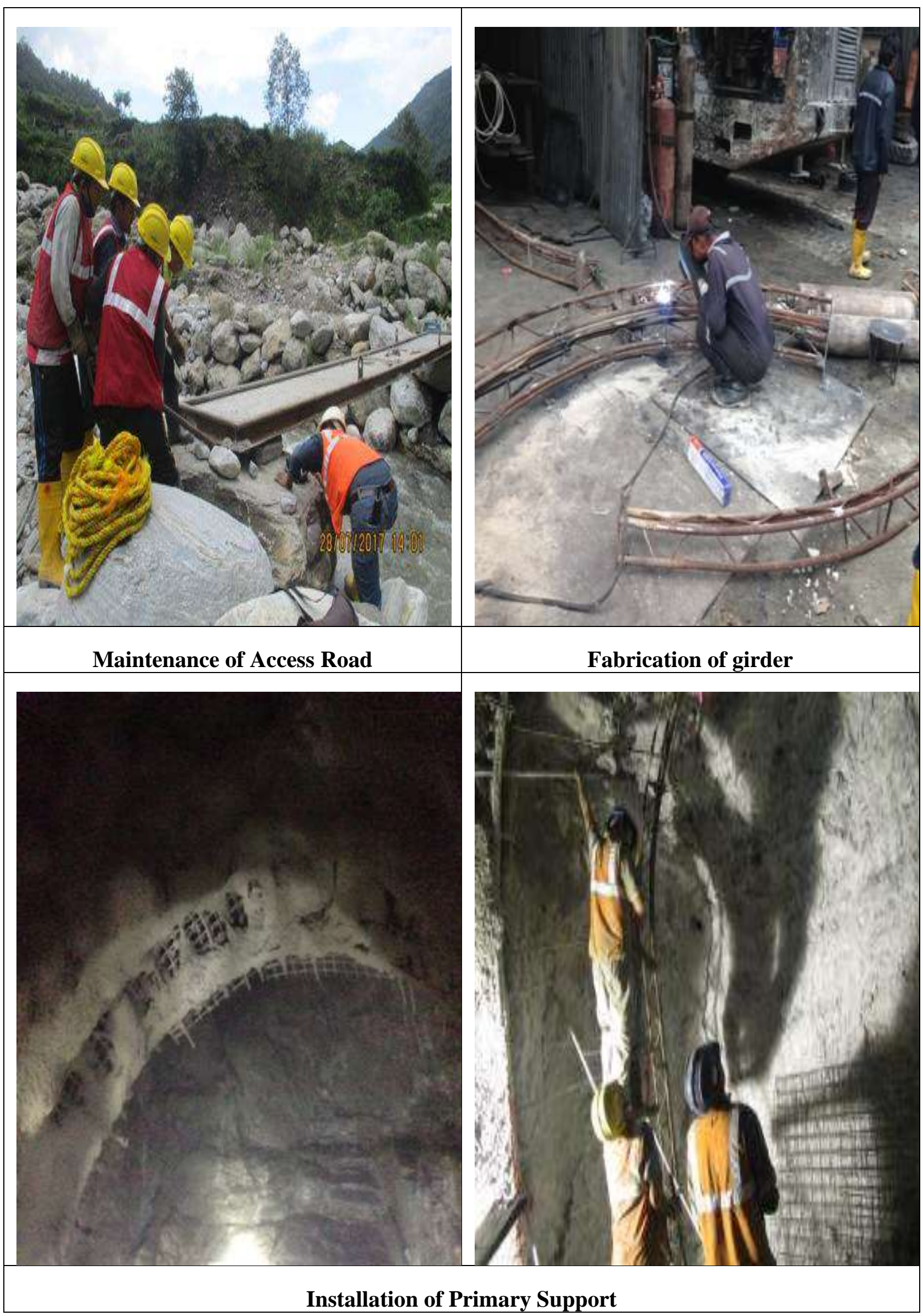




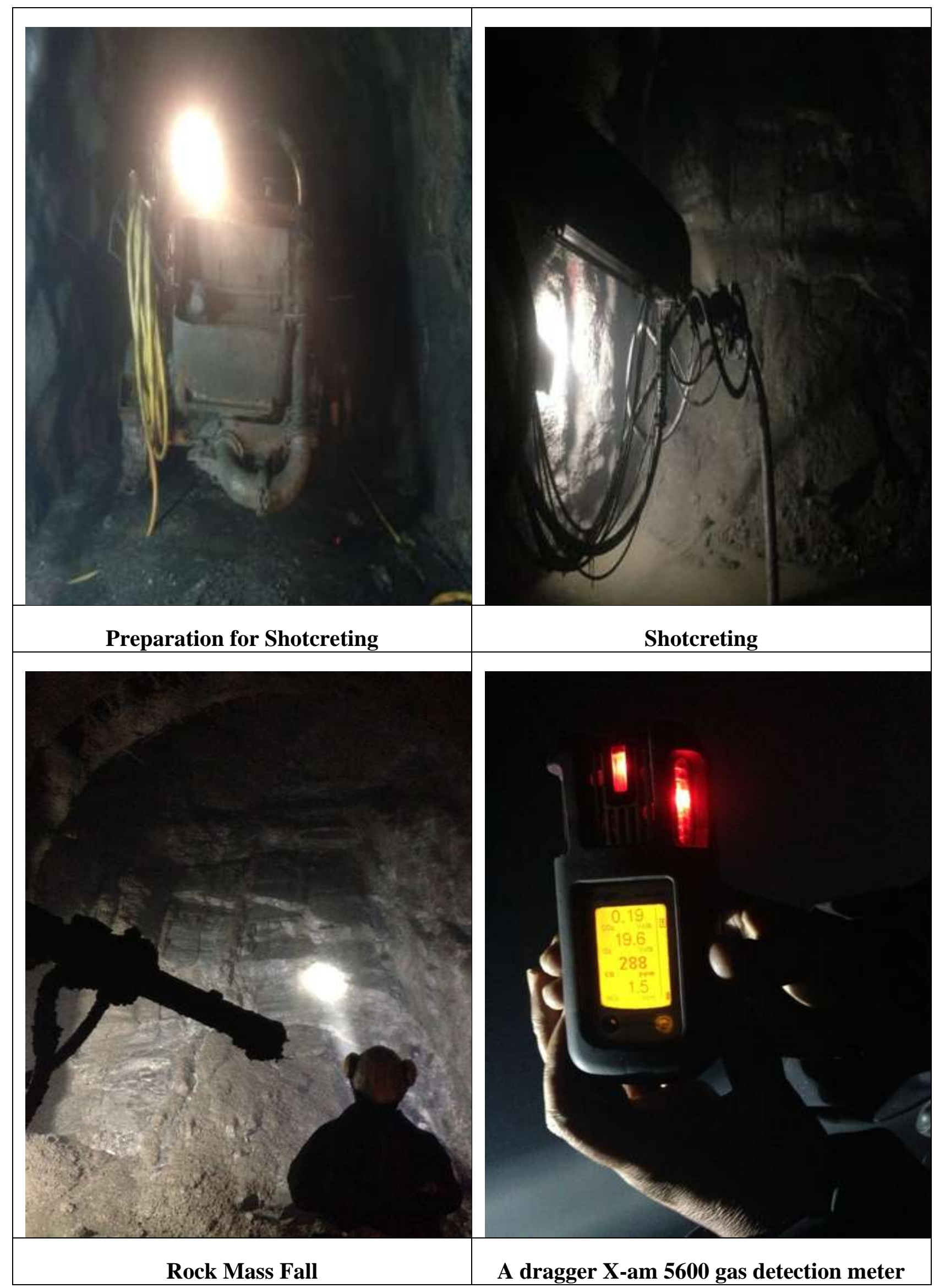




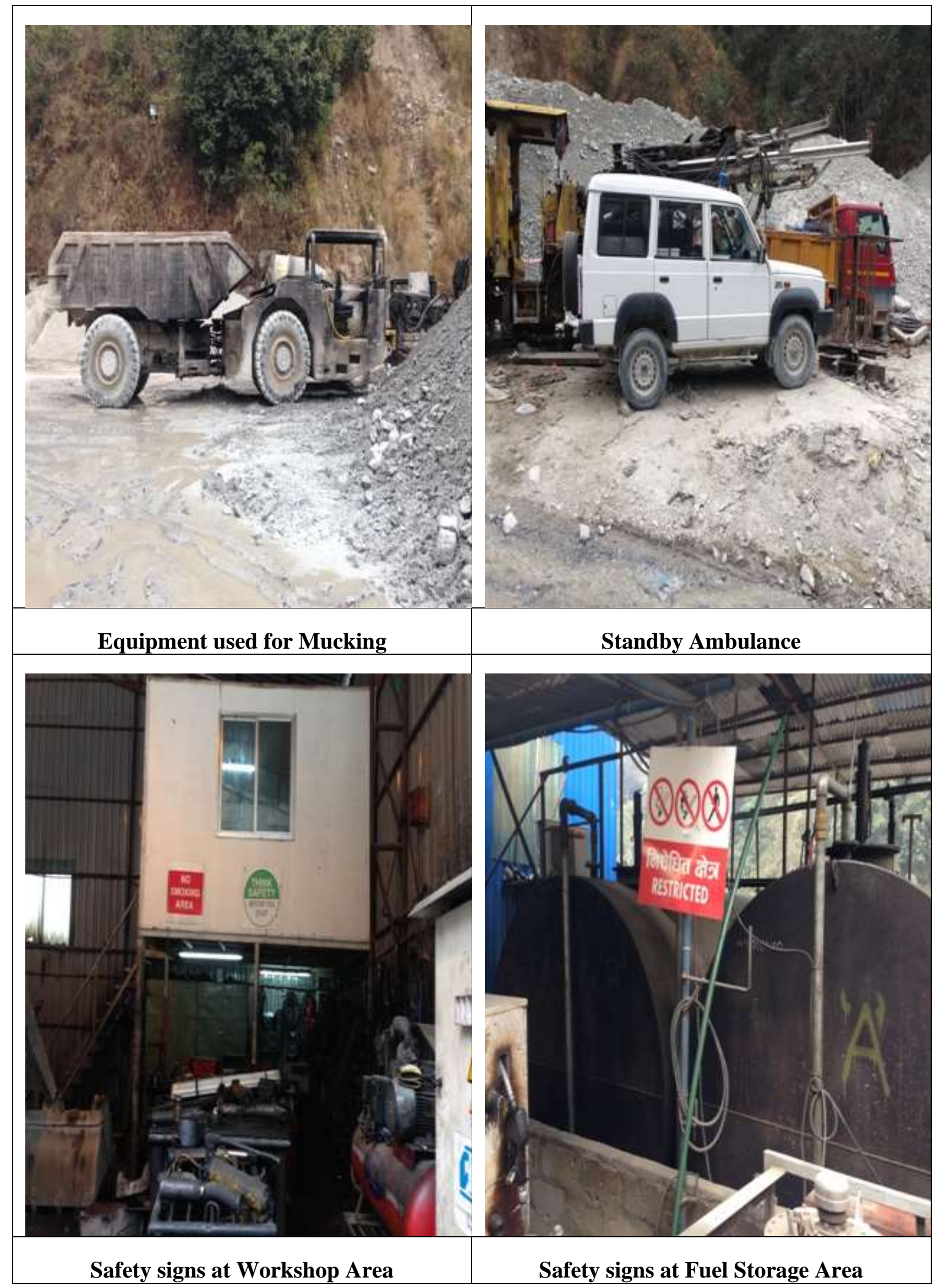




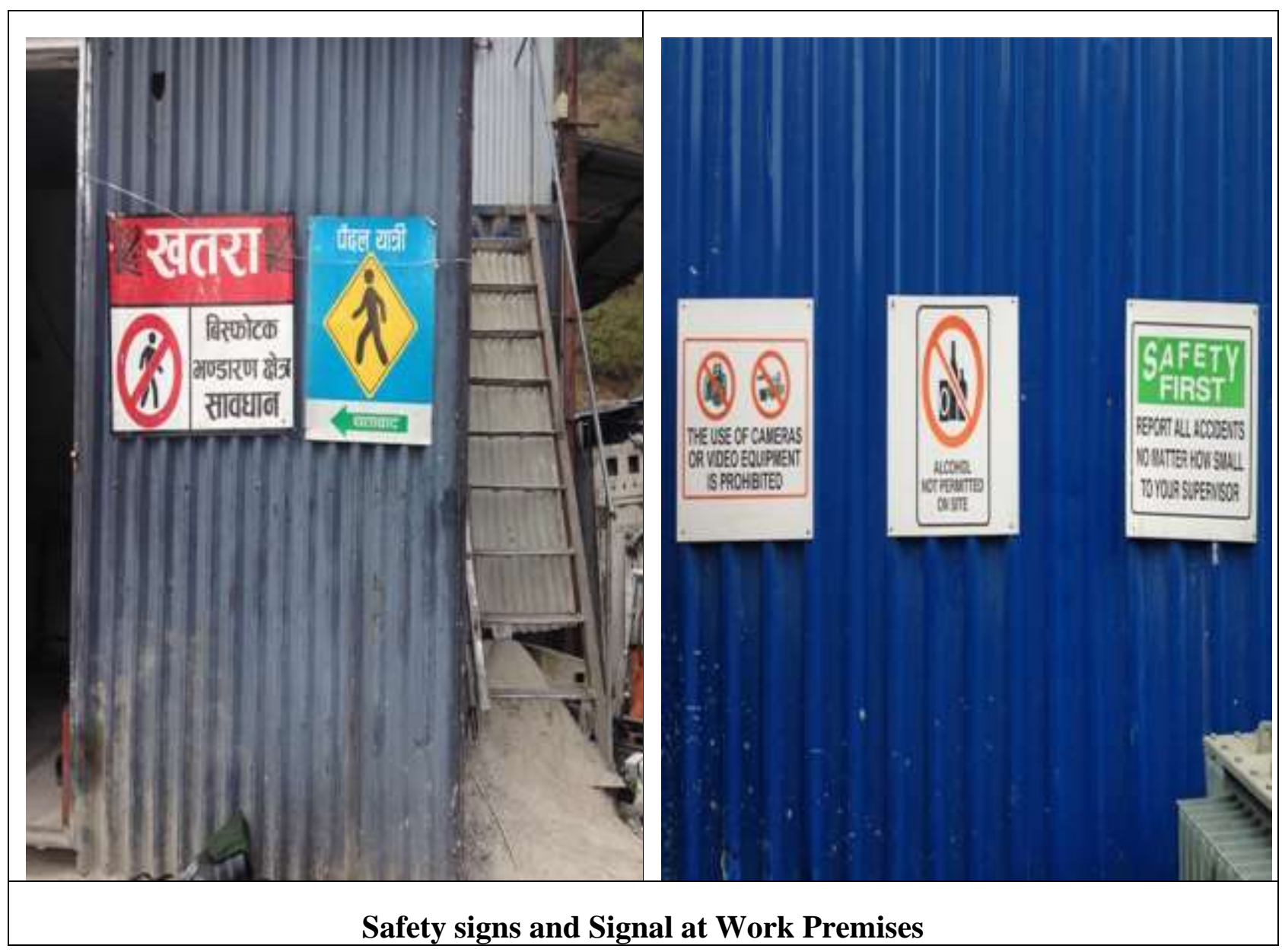

